\title{
Effectiveness of conceptual change texts: A meta analysis*
}

\author{
Fulya Öner Armağan', Melike Özer Keskin² And Beril Salman Akın³ \\ 1 Department of Mathematics and Science Education, Erciyes University, Kayseri, Turkey \\ 2, Department of Mathematics and Science Education, Gazi University, Ankara,Turkey \\ 3 Department of Mathematics and Science Education, Gazi University, Ankara,Turkey \\ For correspondence: onerf@erciyes.edu.tr
}

\begin{abstract}
The purpose of this study was to determine the overall effectiveness of conceptual change texts (CCTs) on academic achievement and to find out if effectiveness was related to some characteristics of the study. It followed up a Metaanalysis research approach. 42 published and unpublished studies, published between 1995 and 2010, and 42 experiment groups' effect sizes were tested in this study. The overall effect size for CCTs was calculated as 1.18. This is a large effect size according to Cohen's criteria. It was found that CCTs have been quite successful in promoting the students' academic success. However results showed that there was no publication bias in respect to publication status. Moreover, no statistically significant difference was found on the nature of assessment instrument, study origin, subject matter, type of instruction, school level, sample size, type of instrument, publication date and duration of treatment. Moreover statistically significant difference was found for instruction effect. The effects of the research results are discussed.
\end{abstract}

Keywords: Conceptual change, conceptual change text, meta-analysis

\section{Introduction}

There have been many studies concerning students' conceptual understanding since 1970's. All these studies' main concern was the importance of on students' prior ideas (Pintrich, Marx ve Boyle, 1993;Scott, Asoko \& Driver, 1992; Smith, diSessa \& Rochelle, 1993; Chambers \& Andre, 1995; Beeth, 1998a). Students come to the classroom with some alternative ideas which contradict scientific ideas (Posner, Strike, Hewson \& Gertzog, 1982; Roth 1985; Gunstone \& Nortfield, 1992; Vosniadou \& Ioannides, 1998). Since conceptions have an active role on teaching and learning, the studies on students' and teachers' conceptions are one of the most important areas of science education research (Pines and West, 1986; Duit \& Treagust, 2003). Students' prior knowledge has an effect on their learning (Pines and West 1986). Hence, determining students' prior knowledge (Beeth, 1998) and fostering a learning environment is quite important (Clough \& Driver, 1986; Carey, 2000).

Many studies concerning alternative concepts have shown that traditional instruction has not fit concept learning and is not effective for removing alternative concepts (Pines and West, 1986; Dykstra, Boyle and Monarch, 1992). Therefore teachers need to take into some alternative strategies for fostering learning outcomes. Conceptual change is one of the effective strategies in science learning (Hewson, 1981; Gunstone \& Nortfield, 1992; Chambers and Andre, 1997; Treagust and Duit, 2008).

\footnotetext{
* This study was presented as an oral presentation at the World Conference on Learning, Teaching and Administration (WCLTA 2010), 29-31 November 2010.

This study has been derived from the first author's doctoral dissertation completed at Gazi University Graduate Institute of Educational Sciences.
} 
Moreover this strategy is quite effective in reducing alternative conceptions (Hewson \& Hewson 1983; Wang \& Andre, 1991; Smith, Blakeslee \& Anderson, 1993).

There are numerous strategies using conceptual change approach. One of them is conceptual change text (CCT) suggested by Roth (1985). Many studies concerning CCTs in science education have shown that this approach is quite effective on increasing students' academic success (Chambers \& Andre, 1997; Wang \& Andre, 1991).

\section{Purpose of the Study}

The purpose of this study was to determine the overall effectiveness of CCTs.on academic achievement and to find out if effectiveness was related to some characteristics of the study. Moreover, in present study, the data were examined to investigate the influence of the type of publication status, publication origin, publication date, subject matter, school level, sample size, length of treatment, nature of assessment instrument, type of instrument, mode of instruction and effects of intervener on the overall effect size. This meta analysis study was expected to contribute in the literature as a comprehensive and updated analysis on the effectiveness of CCTs in science education.

\section{Method}

This study followed up a Meta analysis research approach. The meta analysis refers to an analysis in order to obtain an overall result by combining the results obtained from different studies (Hunter ve Schmidt, 1990). Meta analysis allows the combining of numerical results from a few or many studies (Rosenthal 1991).In meta-analysis, the data obtained in order to bring together the statistical data in different studies needs to be translated to the effect size, which is a common unit of a measurement.

Effect size is a standard measure used in determining the strength of a study. Therefore, in this study effect sizes for studies and experiment groups were calculated using the formula recommended by Hedges and Olkin (1985).In this study only research studies that used a control group and provided adequate statistics for conversion to effect sizes were included. However effect size of each study was calculated and examined for outliers. Then present data analyzed through SPSS 18.1 and Meta Win 1.00 (Rosenberg, Adams \& Gurevitch, 1997). The overall effect size of the all studies was calculated by Meta Win 1.00. In the study, a random effects model was chosen to calculate the mean effect size in the Meta Win 1.00.

\section{Data Collection and Analysis}

Firstly a comprehensive search was done selecting all of the related studies whether published or unpublished. When the studies were being searched during literature review, all studies were examined. Because the aim was to reach all related studies to CCT. To achieve publications in Turkey, Higher Education Council Dissertation Center, Ulakbim and Google Scholar Database was scanned. To achieve related studies, "kavramsal değişim metni", "kavramsal değişim yaklaşımı" keywords were searched in databases. At the end of literature review, a master thesis, a doctoral dissertation and research paper related to CCT was found. The references of all studies were also examined to find relevant studies. All these studies were examined for selecting criteria and then selected studies was coded. Studies which have got insufficient information to calculate the effect sizes, connection to authors had done. The database was updated periodically.

The coding form was developed in order to increase the reliability in the coding of the suitability of the studies involved. Two researchers filled the coding form separately and then reached consensus on non-overlapping coding. To assess the inter-coder reliability, "agreement rate" (AR) was used. The formula for AR, as represented by Cooper \& Hedges (1994) was used. An agreement rate of .85 or 
greater was predetermined to be considered sufficient. An agreement rate of .99 was obtained for this study.

\section{Selection of Studies}

Depending on the inclusion criteria determined and on the availability of the studies, a total of 44 studies were included in the present study. The criteria for inclusion in this study was:

1. The studies on CCTs using pretest-posttest-control group design.

2. The studies examining the effect of CCTs on academic achievement of students

3. The studies including the data of mean scores, standard deviations and sample size for the experimental and control groups in order to calculate effect size.

\section{Findings and Results}

The overall effect size for CCTs was calculated as 1.20. This is a large effect size according to Cohen's criteria. In present study, the data were examined to investigate the influence of the type of publication status, publication origin, publication date, subject matter, school level, sample size, length of treatment, nature of assessment instrument, type of instrument, mode of instruction and effects of intervener on the overall effect size. The results of this analysis are presented in Table 1 to table 11.

Table 1. Effect sizes for publication status.

\begin{tabular}{|c|c|c|c|c|c|c|}
\hline \multirow{2}{*}{$\begin{array}{l}\text { Variable and class } \\
\text { effect }\end{array}$} & \multirow{2}{*}{$\begin{array}{l}\text { Between class } \\
\text { effect (Qbet) }\end{array}$} & \multirow[t]{2}{*}{$\mathrm{n}$} & \multirow{2}{*}{$\begin{array}{l}\mathrm{Me} \\
\text { an } \\
\text { d }\end{array}$} & \multicolumn{2}{|c|}{$\% 95 \mathrm{CI}$ for $\mathrm{d}$} & \multirow{2}{*}{$\begin{array}{l}\text { Homogeneity } \\
\text { within Each } \\
\text { class } Q_{w_{1}}\end{array}$} \\
\hline & & & & $\begin{array}{l}\text { Lower } \\
\text { Upper }\end{array}$ & & \\
\hline Publication status & 0.460 & & & & & \\
\hline Unpublished & & 15 & $\begin{array}{l}1.0 \\
95\end{array}$ & 0,838 & 1,352 & 40.372 \\
\hline Published & & 27 & $\begin{array}{l}1.2 \\
05\end{array}$ & 1,018 & 1,392 & 102,188 \\
\hline
\end{tabular}

${ }^{*} p<.05$

The results of the analysis showed that there were no significant differences between the mean effect sizes of published and unpublished studies ( $\mathrm{Qbet}=0.460, \mathrm{p}=.497)$. The effect sizes for published and unpublished studies were nearly equal and they were $d=1.20$ and $d=1.09$ respectively. These findings represent that there was no publication bias in respect to publication status.

Table2. Effect sizes for study origin

\begin{tabular}{|c|c|c|c|c|c|c|}
\hline $\begin{array}{l}\text { Variable and class } \\
\text { effect }\end{array}$ & $\begin{array}{l}\text { Between } \\
\text { class effect } \\
\text { (Qbet) } \\
\end{array}$ & $\mathrm{n}$ & Mean d & \multicolumn{2}{|c|}{$\begin{array}{l}\% 95 \text { CI for } \mathrm{d} \\
\text { Lower } \\
\text { Upper } \\
\end{array}$} & $\begin{array}{l}\text { Homogeneity } \\
\text { within Each } \\
\text { class } Q_{w 1}\end{array}$ \\
\hline Study Origin & 3.778 & & & & & \\
\hline Doctoral dissertations & & 4 & 0.875 & 0.392 & 1.358 & 5.547 \\
\hline Master theses & & 9 & 1.070 & 0.740 & 1.401 & 23.204 \\
\hline Articles & & 27 & 1.205 & 1.020 & 1.390 & 102.188 \\
\hline Conference papers & & 2 & 1.651 & 0.960 & 2.342 & 1.207 \\
\hline
\end{tabular}

${ }^{*} p<.05$, 
There were no statistically significant differences the mean effect sizes of among doctoral dissertations, master theses, articles and conference papers $\left(Q_{b e t}=3.778, p=.286\right)$. Conference papers attained the highest effect size $(\mathrm{d}=1.651)$. It was followed by articles and master theses.

Table 3. Effect sizes for subject matter

\begin{tabular}{|c|c|c|c|c|c|c|}
\hline \multirow{2}{*}{$\begin{array}{l}\text { Variable and class } \\
\text { effect }\end{array}$} & \multirow{2}{*}{$\begin{array}{l}\text { Between } \\
\text { class effect } \\
\left(Q_{\text {bet }}\right) \\
\end{array}$} & \multirow[t]{2}{*}{$\mathrm{n}$} & \multirow[t]{2}{*}{ Mean d } & \multirow{2}{*}{\multicolumn{2}{|c|}{$\begin{array}{l}\text { \%95 CI for d } \\
\text { Lower } \\
\text { Upper }\end{array}$}} & \multirow{2}{*}{$\begin{array}{l}\text { Homogeneity } \\
\text { within Each } \\
\text { class } Q_{\text {w1 }}\end{array}$} \\
\hline & & & & & & \\
\hline Subject Matter & 3.069 & & & & & \\
\hline Physics & & 14 & 1.103 & 0.847 & 1.358 & 25.251 \\
\hline Chemistry & & 15 & 1.342 & 1.093 & 1.591 & 58.709 \\
\hline Biology & & 13 & 1.037 & 0.772 & 1.302 & 48.434 \\
\hline
\end{tabular}

${ }^{*} p<.05$,

There were no statistically significant differences among the mean effect sizes of the studies on physic, chemistry and biology subject areas $\left(Q_{b e t}=3.069 ; \mathrm{p}=.215\right)$. Considerably strong effects were found for chemistry studies $(\mathrm{d}=1.342)$.

Table 4. Effect sizes for mode of instruction

\begin{tabular}{|c|c|c|c|c|c|c|}
\hline \multirow{2}{*}{$\begin{array}{l}\text { Variable and class } \\
\text { effect }\end{array}$} & \multirow{2}{*}{$\begin{array}{l}\text { Between } \\
\text { class effect } \\
\text { (Qbet) }\end{array}$} & \multirow[t]{2}{*}{$\mathrm{n}$} & \multirow[t]{2}{*}{ Mean d } & \multicolumn{2}{|c|}{$\% 95$ CI for $\mathrm{d}$} & \multirow{2}{*}{$\begin{array}{l}\text { Homogeneity } \\
\text { within Each } \\
\text { class } Q_{\mathrm{w} 1}\end{array}$} \\
\hline & & & & Lower & Upper & \\
\hline Mode of instruction & 2.712 & & & & & \\
\hline Text & & 26 & 1.264 & 1.075 & 1.453 & 99.919 \\
\hline Combination & & 16 & 1.006 & 0.764 & 1.248 & 38.007 \\
\hline
\end{tabular}

* $p<.05$,

There were no statistically significant differences between the mean effect sizes of studies using conceptual change text and mixed studies ( $\mathrm{Qbet}=2.712, \mathrm{p}=.099)$. Also it was found that CCT model has been more successful than mixed studies (CCT combined with other instruction) in promoting the students' academic success.

Table 5. Effect sizes for school level

\begin{tabular}{|c|c|c|c|c|c|c|}
\hline \multirow{2}{*}{$\begin{array}{l}\text { Variable and } \\
\text { class effect }\end{array}$} & \multirow{2}{*}{$\begin{array}{l}\text { Between class } \\
\text { effect (Qbet) }\end{array}$} & \multirow[t]{2}{*}{$\mathrm{n}$} & \multirow[t]{2}{*}{ Mean d } & \multicolumn{2}{|c|}{$\% 95 \mathrm{CI}$ for $\mathrm{d}$} & \multirow{2}{*}{$\begin{array}{l}\text { Homogeneity } \\
\text { within Each } \\
\text { class } Q_{w 1}\end{array}$} \\
\hline & & & & Lower & Upper & \\
\hline School level & 2.739 & & & & & \\
\hline Primary & & 8 & 1.077 & 0.743 & 1.411 & 24.578 \\
\hline Secondary & & 25 & 1.107 & 0.913 & 1.302 & 73.510 \\
\hline University & & 9 & 1.399 & 1.085 & 1.712 & 34.390 \\
\hline
\end{tabular}

$* p<.05$,

There were no statistically significant differences among the mean effect sizes of the studies conducted in primary school, secondary school and university levels ( $Q_{\text {bet }}=2.739, p=.254$ ) and CCT instruction was the most effective in university level. 
Table 6. Effect sizes for sample size

\begin{tabular}{|c|c|c|c|c|c|c|}
\hline \multirow{2}{*}{$\begin{array}{l}\text { Variable and } \\
\text { class effect }\end{array}$} & \multirow{2}{*}{$\begin{array}{l}\text { Between class } \\
\text { effect (Qbet) }\end{array}$} & \multirow[t]{2}{*}{$\mathrm{n}$} & \multirow[t]{2}{*}{ Mean d } & \multicolumn{2}{|c|}{$\% 95 \mathrm{CI}$ for $\mathrm{d}$} & \multirow{2}{*}{$\begin{array}{l}\text { Homogeneity } \\
\text { within Each } \\
\text { class } Q_{w 1}\end{array}$} \\
\hline & & & & Lower & Upper & \\
\hline Sample size & 4.170 & & & & & \\
\hline $\mathrm{n} \leq 25$ & & 12 & 0.975 & 0.688 & 1.261 & 15.617 \\
\hline $25<\mathrm{n} \leq 50$ & & 27 & 1.195 & 1.012 & 1.378 & 87.790 \\
\hline $50<\mathrm{n} \leq 75$ & & 3 & 1.577 & 1.053 & 2.101 & 28.447 \\
\hline
\end{tabular}

Also it was found that there were no statistically significant differences in mean effect sizes of the studies with respect to sample size ( $\left.\mathrm{Qbet}_{\text {bet }} 4.170, \mathrm{p}=.124\right)$.

Table7. Effect sizes for nature of assessment instrument

\begin{tabular}{|c|c|c|c|c|c|c|}
\hline \multirow[t]{2}{*}{ Variable and class effect } & \multirow{2}{*}{$\begin{array}{l}\text { Between } \\
\text { class } \\
\text { effect } \\
\text { (Qbet) } \\
\end{array}$} & \multirow[t]{2}{*}{$\mathrm{n}$} & \multirow[t]{2}{*}{ Mean d } & \multicolumn{2}{|c|}{$\% 95 \mathrm{CI}$ for $\mathrm{d}$} & \multirow{2}{*}{$\begin{array}{l}\text { Homogeneity } \\
\text { within Each } \\
\text { class } Q_{\text {w1 }}\end{array}$} \\
\hline & & & & Lower & Upper & \\
\hline $\begin{array}{l}\text { Nature of assessment } \\
\text { instrument }\end{array}$ & 0.379 & & & & & \\
\hline Experimenter developed & & 29 & 1.168 & 0.983 & 1.353 & 86.520 \\
\hline Standard & & 3 & 1.000 & 0.410 & 1.591 & 4.105 \\
\hline Combination & & 10 & 1.210 & 0.899 & 1.521 & 53.351 \\
\hline
\end{tabular}

${ }^{*} p<.05$,

It was found that there were no statistically significant differences in mean effect sizes of the studies with respect to nature of assessment instrument ( $\left.\mathrm{Q}_{\text {bet }}=0.379, \mathrm{p}=.826\right)$.

Table8. Effect sizes for type of instrument.

\begin{tabular}{|c|c|c|c|c|c|c|}
\hline \multirow[t]{2}{*}{ Variable and class effect } & \multirow{2}{*}{$\begin{array}{l}\text { Between } \\
\text { class effect } \\
\left(Q_{\text {bet}}\right)\end{array}$} & \multirow[t]{2}{*}{$\mathrm{n}$} & \multirow[t]{2}{*}{ Mean d } & \multicolumn{2}{|c|}{$\% 95 \mathrm{CI}$ for $\mathrm{d}$} & \multirow{2}{*}{$\begin{array}{l}\text { Homogeneity } \\
\text { within Each class } \\
\mathrm{Q}_{\mathrm{w} 1}\end{array}$} \\
\hline & & & & Lower & Upper & \\
\hline Type of instrument & 0.111 & & & & & \\
\hline Multiple choice test & & 27 & 1.163 & 0.971 & 1.356 & 84.642 \\
\hline Two tier test & & 10 & 1.142 & 0.822 & 1.462 & 50.926 \\
\hline Three tier test & & 5 & 1.233 & 0.793 & 1.674 & 9.115 \\
\hline
\end{tabular}

${ }^{*} p<.05$,

It was found that there were no statistically significant differences in mean effect sizes of the studies with respect to type of instrument ( $\left.\mathrm{Q}_{\mathrm{bet}}=.111, \mathrm{p}=.945\right)$.

Table 9. Effect sizes for publication date

\begin{tabular}{|c|c|c|c|c|c|c|}
\hline \multirow{2}{*}{$\begin{array}{l}\text { Variable and } \\
\text { class effect }\end{array}$} & \multirow{2}{*}{$\begin{array}{l}\text { Between class } \\
\text { effect (Qbet) }\end{array}$} & \multirow[t]{2}{*}{$\mathrm{n}$} & \multirow[t]{2}{*}{ Mean d } & \multicolumn{2}{|c|}{$\% 95 \mathrm{CI}$ for $\mathrm{d}$} & \multirow{2}{*}{$\begin{array}{l}\text { Homogeneity } \\
\text { within Each } \\
\text { class } Q_{w 1} \\
\end{array}$} \\
\hline & & & & Lower & Upper & \\
\hline Publication date & 1.654 & & & & & \\
\hline 1995-1999 & & 3 & 0.978 & 0.421 & 1.536 & 2.735 \\
\hline 2000-2005 & & 14 & 1.075 & 0.813 & 1.337 & 47.637 \\
\hline
\end{tabular}


${ }^{*} p<.05$,

It was found that there were no statistically significant differences in mean effect sizes of the studies with respect to the publication date (Qbet $=1.654, \mathrm{p}=.=.43733)$.

Table 10. Effect sizes for duration of treatments

\begin{tabular}{|c|c|c|c|c|c|c|}
\hline \multirow{2}{*}{$\begin{array}{l}\text { Variable and class } \\
\text { effect }\end{array}$} & \multirow{2}{*}{$\begin{array}{l}\text { Between } \\
\text { class effect } \\
\text { (Qbet) }\end{array}$} & \multirow[t]{2}{*}{$\mathrm{n}$} & \multirow[t]{2}{*}{ Mean d } & \multicolumn{2}{|c|}{$\% 95 \mathrm{CI}$ for $\mathrm{d}$} & \multirow{2}{*}{$\begin{array}{l}\text { Homogenity } \\
\text { within Each } \\
\text { class } Q_{w_{1}}\end{array}$} \\
\hline & & & & Lower & Upper & \\
\hline $\begin{array}{l}\text { Duration of } \\
\text { treatments } \\
2-4 \text { weeks }\end{array}$ & 2.362 & & & & & \\
\hline 4-6 weeks & & 27 & 1.202 & 1.202 & 1.388 & 98.618 \\
\hline 6-8 weeks & & 11 & 1.014 & 0.722 & 1.306 & 24.422 \\
\hline Unspecified & & 4 & 1.442 & 0.946 & 1.937 & 12.654 \\
\hline
\end{tabular}

* $p<.05$,

It was found that there were no statistically significant differences in mean effect sizes of the studies with respect to duration of treatments (Qbet $=2.362, p=.306)$.

Table 11. Effect sizes by instructor effect

\begin{tabular}{|c|c|c|c|c|c|c|}
\hline \multirow{2}{*}{$\begin{array}{l}\text { Variable and class } \\
\text { effect }\end{array}$} & \multirow{2}{*}{$\begin{array}{l}\text { Between } \\
\text { class effect } \\
\text { (Qbet) }\end{array}$} & \multirow[t]{2}{*}{$\mathrm{n}$} & \multirow[t]{2}{*}{ Mean d } & \multicolumn{2}{|c|}{$\% 95 \mathrm{CI}$ for $\mathrm{d}$} & \multirow{2}{*}{$\begin{array}{l}\text { Homogeneity } \\
\text { within Each } \\
\text { class } Q_{w 1}\end{array}$} \\
\hline & & & & Lower & Upper & \\
\hline Instructor & 4.159 & & & & & \\
\hline Researcher & & 14 & 1.380 & 1.129 & 1.632 & 56.886 \\
\hline Classroom Teacher & & 28 & 1.061 & 0.884 & 1.237 & 72.901 \\
\hline
\end{tabular}

${ }^{*} p<.05$,

Instructor effect was a factor that affecting students' academic success. It was found that there were statistically significant differences in mean effect sizes of the studies with respect to instructor effect $\left(Q_{b e t}=4.159, \mathrm{p}=.041\right)$. It was found that researchers were more effective than classroom teachers on performing the method successfully.

\section{Discussion and Conclusion}

In this meta-analysis, 42 experimental groups having the necessary data to estimate the effect size were determined. Effect sizes were calculated from the 42 studies. The overall effect size for CCTs was calculated as 1.18 of the $95 \%$ confidence interval (1.019-1.314). This is a large effect size according to Cohen's criteria. Moreover, a Z-score of 1.20 corresponds to the 88 th percentile in a standardized normal distribution. This means that, the students instructed with CCTs achieved $88 \%$ more success than the traditional students. This means that CCTs have been more effective than the traditional instruction. This finding is consistent with the results of some other studies (Al khawaldeh, 2007; Al khawaldeh \& Al Olaimat, 2010; Alparslan, Tekkaya \& Geban 2003; Çetin, Ertepinar \& Geban, 2015; Özkan, Tekkaya \& Geban, 2004; Yürük, 2007; Dilber \& Düzgün, 2007; Taştan, Yalçınkaya \& Boz, $2008 b)$.

It is expected that the average effect of published studies will be greater because the probability of publication of studies giving statistically significant results is higher (Rosenthal, 1991; Cooper and 
Hedges, 1994). In this meta-analysis study, 27 published studies (articles) and 15 unpublished studies (master thesis, doctoral dissertations and conference papers) were analyzed. Both published and unpublished studies gave similar results in terms of effect sizes. These findings indicated that there was no publication bias in respect to publication status. It can be indicated with confidence that the sample of studies used in this meta-analysis was representative of the population of studies relating to CCTs.

In this meta-analysis study, 27 articles, 9 master theses, 4 PhD dissertations, and 2 conference papers providing the criteria were analyzed. Effect sizes of all studies were high. When the analyses were examined, it was found that there is no significant difference between the effect sizes of these four groups. It was seen that the conference papers (only two) have the highest effect size. However, more conference papers should be included in order to generalize the results.

In the study, the largest mean effect was found in the chemistry studies $(\mathrm{d}=1.342)$, suggesting that CCTs is most effective in chemistry. Moreover in the fields of physics and biology, a high mean effect was also found, the values were $d=1.103$ and $d=1.037$, respectively. On the other hand, there were no statistically significant differences among the mean effect sizes of physics, chemistry and biology subject areas (Qbet= 3.069; $\mathrm{p}=.215$ ). This means that, the effect size of the CCTs does not differ according to the subject matter applied.

In the literature, there are two main trends related to CCTs. First, the studies compare the CCT with the traditional method. Second, the studies compare the CCT accompanied another method with the traditional method. The number of studies which compare the conceptual change approaches among themselves is scarce (Balc1, 2005; Okur, 2009; Durmuş and Bayraktar, 2010). Hence, more research is needed to make such comparisons. Thus, it can be determined which technique will yield more effective results for conceptual change. In literature, the studies using two methods (CCTs accompanied by any other method) support the idea that these methods can eliminate each other's deficiencies and more effective results can be achieved (Guzzetti et al., 1997; Hynd et al.,1997; Harrison and Treagust, 2001; Ünal, 2007; Sevim, 2007; Okur, 2009). For a better understanding of which instruction was the most effective, 26 studies which use CCTs and 16 studies which use both CCTs and additional another technics were analyzed in this study. Considering the effect sizes between these approaches, is was found that there is no significant difference between the effect sizes of these two approaches $(\mathrm{QB}=2.712 ; \mathrm{p}=.099)$. That is to say, the effects sizes of studies do not differ according to the type of instruction used.

To investigate the effect size of the studies with respect to learning level, the studies were divided into three categories; primary, secondary and university. The CCT method was found to be most effective at university level $(\mathrm{d}=1.399)$. This method was also found to be effective at primary and secondary levels as well (respectively $d=1.077$ ve $d=1.107$ ). This meta analysis indicated that there is no significant effect size differences between the studies in terms of different school levels. $(\mathrm{QB}=2.739 ; \mathrm{p}$ $=.254$ ). Although, it has been found that the university level studies have more effective results, CCT method have an effect for all levels, therefore; this method can also be used in the primary and secondary levels.

It was found that there was no significant difference between the mean effect sizes of the groups according to sample size in the study $(\mathrm{QB}=4.170 ; \mathrm{p}=.124)$. High effect sizes were determined for all sample sizes and these values were calculated as $d=0.975, d=1.195$ and $d=1.577$ for low, medium and large learning levels, respectively.

In this meta-analysis study, 29 tests developed by researchers, three standard test, and 10 mix tests were analyzed. When the analyses were examined, it was found that there is no significant difference 
between the effects sizes of these three groups. Also, it was found that the tests developed by the researchers are more effective than the standard tests. This result is parallel with another metaanalysis studies examining the effectiveness of the researcher made or standard tests (Bayraktar, 2000; Başol Göçmen, 2003).

The test type was considered as another feature that is considered to have an effect on the metaanalysis work related to the CCTs due to its importance in determining the alternative concepts. Multiple choice test was used at $69 \%$ in the studies included in this meta-analysis study. In the literature, it is stated that the use of two-tier or three-tier tests is more effective in determining the misconceptions of students (Eryllmaz and Sürmeli, 2002; Mutlu and Özel, 2008). It was found that, although there was no significant difference between the mean effect sizes of these groups in this study, the studies using the three-tier test had greater effect size $(\mathrm{QB}=0.111 ; \mathrm{p}=.945)$. When the literature related to CCT was examined, it was found that studies were usually used multiple-choice tests. However, it was noticed that two tier or three tier tests have also been used. Two-tier tests consist of two parts. The first stage consists of a multiple choice question and the second stage consists of the part where the explanation of the reason for the selection of the answer to the first stage is desired. The second stage can be a multiple-choice or open-ended question. The three-tier tests consist of three parts. The difference of the three-tier test from the two-tier test is that it is made up of an additional third part that is questioned about the degree of assurance of the answers given to the first two steps. Multiple choice tests are preferred because of their ease of implementation in large samples and their easy analysis of results (Eryılmaz ve Sürmeli, 2002). Though there are advantages of multiple-choice tests, two-tier and three-tier tests are more useful in emerging alternative concepts in students since students explain the reasons of their answers (Dikmenli, Türkmen, Çardak ve Kurt, 2005; Bilgin, 2006; Efe, 2007; Gürdal, 2008; Özdemir, 2008).

When the studies were classified according to the publication year, it was observed that there has been a big increase in the number of studies related to CCTs in the last five years. The effect size of the publications of the last five years had the largest value compared to the other years, whereas the high effect size was determined in all categories of the publishing year. There was no significant difference between the mean effect sizes of the groups $(\mathrm{QB}=1.654 ; \mathrm{p}=.437)$. The fact that the effect size value of recent years was higher indicates that the researches carried out today could planned in detail and made under better conditions. In addition, new studies are designed in line with the proposals of the previous studies and aim to overcome the limitations of older studies.

A large majority $(64 \%)$ of the studies lasted for 4-6 weeks. High effect size was determined in all categories of the treatment period. However, it was found that there is no significant difference between the mean effect sizes of the durations of the studies $(\mathrm{QB}=2.362 ; \mathrm{p}=.306)$. The effect size was found to be higher for 4-6 weeks when the application period was minimum. This may be a sign that as the duration of application increases, the students become bored and the number of students decreased, and therefore the effect of the method may be diminished.

In this study, the influence of the practitioners was determined as the only significant factor by affecting student achievement. According to the analysis results, it was determined that there were statistically significant differences between the mean effect sizes of the groups. It was found that the researcher practitioner is more effective than the classroom teacher practitioner. This suggested that the researcher is more prevalent in the subject or that sufficient information or training on the practice may not be given to the classroom teacher. 


\section{Suggestions}

\section{The suggestions regarding the results of meta-analysis:}

1. The detailed information about researchers should be given in the studies regarding CCTs.

2. The implementer and the researcher should not be same person in the studies regarding CCTs.

3. The implementer should be educated about the implementation by the researcher.

4. The duration of implementation should clearly be stated.

5. The professional experience of the implementer and his/her pedagogical content knowledge should be expressed clearly.

6. The studies about CCTs should be conducted on primary and university students.

7. The studies about CCTs accompanied by analogy, concept map, computer assisted instruction should be conducted.

8. Retention tests should be administered in the experimental studies after the administration of pre- and post-tests in order to increase the reliability of study.

9. The implementation of CCTs in the classroom should be given enough time.

10. The ideas of students should be taken into account on how to implement CCTs in order to increase the effect of CCTs.

\section{Suggestions regarding the researchers}

1. The future researchers should evaluate the effect size of their studies comparing the effect size of this study $(\mathrm{d}=1.18)$.

2. The researchers who will conduct a meta-analysis study should contact the researcher who did not give detailed information about his or her study.

3. Unpublished researchers should be included to the meta-analysis studies.

4. The meta-analysis programs (e.g. Metawin 1.0) should be compared in terms of advantages and disadvantages of them.

5. More meta-analysis research should be conducted to examine the effect of CCTs on attitude.

6. More meta-analysis research should be conducted to examine the effect of analogy, computer assisted instruction.

7. This study states that the number of studies which use two or three tier tests is quite few. Therefore, these tests should be used in the studies about CCTs and the studies examining the students' misconceptions.

\section{The suggestions regarding science education and curriculum development}

1. The results of meta-analysis studies should be used in the studies of curriculum development

2. The curriculum developers should suggest the usage of CCTs to the chemistry, physics, and biology teachers since these studies have large effect size.

3. In-service training courses about CCTs should be arranged for the science teachers. Also, a course about CCTs should be defined for the education faculties.

4. Textbook writers and textbook evaluation committee should pay attention to the concept teaching in order to eliminate misconceptions of students.

5. The studies planned to be done on CCTs should be considered as priority by Ministry of National Education and The Scientific and Technological Research Council of Turkey.

\section{References}

Al khawaldeh, S. A. \& Al Olaimat, A. M. (2010). The contribution of conceptual change texts accompanied by concept mapping to eleventh-grade students understanding of cellular respiration. Journal of Science Education and Technology, 19(2), 115125

Beeth, M. E. (1998a). Teaching science in fifth grade: instructional goals that support conceptual change. Journal of Research in Science Teaching, 35 (10), 1091-1101

Beeth, M. E. (1998b). Teaching for conceptual change: Using status as a metacognitive tool. Science Education, 82 (3), 343-356.

Carey, S.(2000). Science education as conceptual change, Journal of Applied Developmental Psychology, 21(1), 13-19. 
Chambers, K. S., \& Andre, T. (1997). Gender, prior knowledge, interest and experience in electricity and conceptual change text manipulations in learning about direct current, Journal of Research in Science Teaching, 34, 107-123.

Cohen, J. (1977). Statistical power analysis for the behavioral science (Rev.Ed.). New York: Academic Press.

Cooper, H., \& Hedges, L. (Eds.). (1994). The handbook of research synthesis. New York: Russell Sage Foundation

Çetin, G., Ertepinar, H., \& Geban, Ö. (2015). Effects of conceptual change text based instruction on ecology, attitudes toward biology and environment. Educational Research and Reviews, 10(3), 259-273.

Duit, R., \& Treagust, D. F. (2003). Conceptual change: a powerful framework for improving science teaching and learning. International Journal of Science Education, 25(6,) $671-688$

Dykstra, D.I., Boyle, C.F., \& Monarch, I.A. (1992). Studying conceptual change in learning physics. Science Education, 76 (6), 615652

Gunstone, R. F., \& Northfield, J. (1992). Conceptual change in teacher education: The centrality of metacognition. Paper presented at the Annual Meeting of the American Research Association, San Francisso, CA.

Hedges, L. V., \& Olkin, I. (1985). Statistical methods for meta-analysis. Orlando. FL: Academic Press.

Hewson, P.W. (1981). A conceptual change approach to learning science. Eureopen Journal of Science Education, 3(4), 383-396.

Hewson, M.G., \& Hewson, P.W. (1983). Effect of instruction using students' prior knowledge and conceptual change strategies on science learning, Journal of Research in Science Teaching, 20 (8), 731-743.

Hunter, J. E. \& Schmidt, F. (1990). Methods of meta-analysis. Newbury Park, CA: Sage publications.

Pines, A., \& West, L., 1986. Conceptual understanding and science learning: an interpretation of research within sources of knowledge framework. Science Education, 70 (5), 583-604.

Pintrich, P.R., Marx, R.W., \& Boyle, R.B. (1993). Beyond cold conceptual change: the role of motivational beliefs and classroom contextual factors in the process of conceptual change. Review of Educational Research, 63(2):167-199.

Posner, G. J., Strike, K. A., Hewson, P.W., \& Gertzog, W. A. (1982) Accommodation of a scientific conception: toward a theory of conceptual change. Science Education, 66(2), 211-227.

Rosenberg, M. S., Adams, D. C., \& Gurevitch, J.(1997). MetaWin: Statistical Software for Meta-analysis with Resampling Tests. Version 1.0. Sunderland, MA: Sinauer Associates.

Rosenthal, R. (1991). Meta-analytic procedures for social research (Rev. ed.). Newbury Park, CA: Sage Pub.

Roth, K. J. (1985). Conceptual change learning and student processing of science texts. Paper presented at the Annual Meeting of the American Educational Research Association (69th, Chicago, IL).

Scott, P., Asoko, H., \& Driver, R. (1992). Teaching for conceptual change: A review of strategies. In Duit, R., Goldberg, F. \& Niedderer (Eds.) Research in Physics Learning: Theoretical issues and empirical studies, Kiel, Germany: IPN, 310-329

Smith L. E., Blakeslee. D. T.. \& Anderson. W. C. (1993). Teaching strategies associated with conceptual change learning in science. Journal of Research in ScienceTeaching, 30 (2) 111-126.

Smith, J.P., diSessa, A.A., \& Rochelle, J. (1993). Misconceptions reconceived: a constructivist analysis of knowledge in transition, The Journal of Learning Sciences, 3 (2), 115-163

Treagust, D., \& Duit, R. (2008). Conceptual change: A discussion of theoretical, methodological and practical challenges for science education. Cultural Studies of Science Education, 3(2), 297-328.

Tsai, C. C. (2004). Conceptions of learning science among high school students in Taiwan: A phenomenographic analysis. International Journal of Science Education, 26, 1733-1750.

Vosniadou, S., \& Ioannides, C. (1998). From conceptual development to science education: a psychological point of view. International Journal of Science Education, 20(10), 1213 - 1230

Wang, T., \& Andre, T., (1991). Conceptual change text versus traditional text and application questions versus no questions in learning about electricity. Contemporary Educational Psychology, 16( 2), 103 - 116

\section{Bibliography of Studies Included in Meta-Analysis}

Alkhawaldeh, S. A. (2007). Facilitating conceptual change in ninth grade students' understanding of human circulatory system concepts. Research in Science \& Technological Education, 25 (3), 371- 385.

Altun, S., Turgut, Ü. \& Büyükkasap, E. (2007). Kavramsal Değisim Metinlerinin Üniversite Öğrencilerin Geometrik Optik Konusundaki Kavram Yanllglarmm Düzeltilmesine ve Tutumlarna Etkisi [The Effect of Conceptual Change Texts on the Correction and Attitude of University Students' Conceptual Misconceptions on Geometric Optics].16. Ulusal Eğitim Bilimleri Kongresi, Gaziosmanpaşa Üniversitesi, Eğitim Fakültesi, Tokat, 5-7 Eylül 2007.

Alparslan, C., Tekkaya, C., \& Geban, O. (2003). Using the conceptual change instruction to improve learning. Journal of Biological Education, 37(3), 133-137.

Aydın, S. (2007). Geometrik Optik Konusundaki Kavram Yanılgllarımın Kavramsal Değişim Metinleri İle Giderilmesi [Elımınatıng The Mısconceptıons About Geometrıc Optıcs By Conceptual Change Texts]. Yayınlanmamış Doktora Tezi, Atatürk Üniversitesi, Fen Bilimleri Enstitüsü, Erzurum.

Balc1, C. (2006). Conceptual change text oriented instruction to facilitate conceptual change in rate of reaction concepts. Unpublished Master's Thesis, The Middle East Technical University, Ankara.

Baser, M., \& Geban, Ö. (2007a). Effectiveness of conceptual change instruction on understanding of heat and temperature concepts, Research in Science \& Technological Education, 25(1), 115 - 133.

Bayar, D. (2009). Kavramsal Değişim Yaklaşımının İlköğretim 8. Simı Öğrencilerinin Fotosentez ve Bitkilerde Solunum Konusunu Anlamalarma Etkisi [The Effect of Cnceptual Change Approach on $8^{\text {th }}$ Grade Students' Understanding of Photosentesis and Respiration in Plants Concepts]. Yayınlanmamış Yüksek Lisans Tezi. Sakarya Üniversitesi, Fen Bilimleri Enstitüsü, Sakarya. 
Cerit Berber, N. \& Sarı, M. (2009). Kavramsal Değişim Metinlerinin İş, Güç, Enerji Konusunu Anlamaya Etkisi [The Effect of Conceptual Change Texts on Work, Power and Energy]. Selçuk Üniversitesi Ahmet Keleşoğlu Eğitim Fakültesi Dergisi, 27, $159-172$.

Çakır, Ö.S., Geban, Ö., \& Yürük, N. (2002). Effectiveness of conceptual change text oriented instruction on students' understanding of cellular respiration concepts. Biochemistry and Molecular Biology Education. 30(4), 239-243

Çaycı, B. (2007). Kavram Değiştirme Metinlerinin Kavram Öğrenimi Üzerindeki Etkisinin İncelenmesi [The Effect of Conceptual Change Texts on The Concept Learning] G.Ü., Gazi Ĕ̆itim Fakültesi Dergisi, 27(1), 87-102.

Çelebi, Ö. (2004). Effect of conceptual change oriented instruction on removing misconceptions about phase changes. Unpublished Master's Thesis, Middle East Technical University, Ankara.

Çetin, G., Ertepınar, H., \& Geban,Ö. (2004). Developing and ımplementing an instructional technology aided conceptual change approach in teaching ecology concepts at ninth grade. The Turkish Online Journal of Educational Technology, 3(1), 27-31.

Çetingül, P.İ. \& Geban, Ö. (2005). Kavramsal Değişim Metodu Kullanarak Asit- Baz Konusunun Anlaşılması. [Understandıng Of Acıd-Base Concept By Usıng Conceptual Change Approach].Hacettepe Üniversitesi Eğitim Fakültesi Dergisi, 29, 69-74.

Demircioğlu, G. (2009).Comparison of the effects of conceptual change texts implemented after and before instruction on secondary school students' understanding of acid-base concepts. Asia-Pacific Forum on Science Learning and Teaching, 10(2), 1-29.

Dilber, R. (2006). Fizik Ö̆̆retiminde Analoji Kullanımının ve Kavramsal Değişim Metinlerinin Kavram Yanılgılarımın Giderilmesine Ve Öğrenci Başarısına Etkisinin Araştırılması. [An Investıgatıon On The Effects Of Analogy And Conceptual Change Text On Remediatıng Of Mısconceptions And Student Success In Physıcs Teaching]. Yayınlanmamış Doktora Tezi. Atatürk Üniversitesi Fen Bilimleri Enstitüsü, Erzurum.

Dilber, R. \& Düzgün, B. (2007). An investigation of effectiveness of conceptual change text-oriented instruction on students' understandings of brightness concepts. Journal of Science Education, 8 (1), 46-52.

Dilber, R., Karaman, I., \& Duzgun, B. (2009). High school students' understanding of projectile motion concepts. Educational Research and Evaluation, 15(3), 203 -222.

Dilber, R. (2010). Effect of conceptual change instruction on students' understanding of electricity concepts. International Journal of Innovation and Learning, 7(4), 478-496.

Doğru, P. (2002). Improving conceptual change concerning diffusion and osmosis through a combined strategy: concept mapping and conceptual change text, Unpublished Master's Thesis, The Middle East Technical University, Ankara.

Durmuş, J. (2009). Illköğretim Fen Bilgisi Dersinde Kavramsal Değişim Metinlerinin ve Deney Yönteminin Akademik Başarıya ve Kavram Yanılgiların Gidermeye Etkisi [Effects Of Conceptual Change Text And Experıment Method On Academic Achrevement And Overcoming Mısconceptıons In Elementary School Scıence And Technology Educatıon]. Yayımlanmamış Yüksek Lisans Tezi, Selçuk Üniversitesi Sosyal Bilimler Enstitüsü, Konya.

Geban, Ö., \& Bayır, G. (2000). Effect of conceptual change approach on students' understanding of chemical change and conservation of matter. Hacettepe Universitesi Ĕ̆itim Fakültesi Dergisi, 19, 79-84.

Gökce, M. (2002). Kavramsal Değişim Metinlerinin Kavram Yanılgılarını Gidermedeki Etkililiği [The Effect of Conceptual Change Texts on Conceptual Misconceptions].Yayınlanmamış Yüksek Lisans Tezi, Ankara Üniversitesi Eğitim Bilimleri Enstitüsü, Ankara.

Gülçiçek (Yüksel), N. (2004). Kavramsal Değiş̧im Metinlerinin Öğrencilerin Manyetizma Konusunu Anlamalarına ve Fizik Tutumlarına Etkisi [The Effect of Conceptual Change Texts on Students' Understanding of Magnetism and Physics Attitudes].Yayılanmamış Yüksek Lisans Tezi. Gazi Üniversitesi, Eğitim Bilimleri Enstitüsü, Ankara.

Hırça, N. (2008). 5e Modeline Göre "İş, Güç Ve Enerji”" Ünitesiyle İlgili Geliştirilen Materyallerin Kavramsal Değişime Etkisinin Incelenmesi [An Investigation Of Effects On Conceptual Change Of Developed Materials Based On 5e Model In Unit “Work, Power And Energy"] Yayınlanmamış Doktora Tezi, Atatürk Üniversitesi Fen Bilimleri Enstitüsü, Erzurum.

Kılıç, S., Ünal, A. ve Türkmen, L. (2006). Kavram Haritaları ve Kavramsal Değişim Metinlerinin Lise I Öğrencilerinin Biyoloji Dersi Başarılarına ve Tutumlarına Etkisi [The Effect of Concept Maps and Conceptual Change Texts on the Success and Attitudes of the Biology Lessons of High School I Students].VII. Ulusal Fen Bilimleri ve Matematik Eğitimi Kongresi, 07-09 Eylül, Gazi Üniversitesi, Gazi Eğitim Fakültesi, Ankara.

Köse, S., Ayas, A., \& Uşak, M. (2006). The effect of conceptual change texts instructions on overcoming prospective science teachers' misconceptions of photosynthesis and respiration in plants. Internatinal Journal of Environmental and Science Education, 1(1) , 78-103.

Önder, İ. \& Geban, Ö. (2006). Kavramsal Degişim Metinlerine Dayalı Ögretimin Örgencilerin Çözünürlük Dengesi Konusunu Anlamasına Etkisi [The Effect Of Conceptual Change Approach On Students' Understandıng Of Solubılity Equilibrium Concept]. Hacettepe Üniversitesi Ĕ̆gitim Fakültesi Dergisi, 30, 166-173.

Özkan, Ö., Tekkaya, C., \& Geban, O. (2004) Facilitating conceptual change in students' understanding of ecological concepts, Journal of Science Education and Technology, 13, 95-105.

Özkaya, A.R., Üce, M., Sançayir, H., \& Şahin, M. (2006). Effectiveness of conceptual change-oriented teaching strategy to improve students' understanding of electrochemistry concerning galvanic cells. Journal of Chemical Education, 83(11): 1719-1723.

Özmen, H., \& Demircioğlu, G. (2003). Asitler ve bazlar konusundaki öğrenci yanlıs anlamalarının değerlendirilmesinde kavramsal değisim metinlerinin etkisi [The Impact of Conceptual Change Texts on Assessing Misunderstandings of Students on Acids and Bases]. Milli Ĕ̆gitim Dergisi, 159, 111-119.

Özmen, H. (2007). The effectiveness of conceptual change texts in remediating high school students' alternative conceptions concerning chemical equilibrium. Asia Pasific Education Review 8(3):413-425. 
Özmen H, Demircioglu, H., \& Demircioglu, G. (2009). The effects of conceptual change texts accompanied with animations on overcoming 11th grade students' alternative conceptions of chemical bonding. Computer Education, 52(3):681-695.

Taştan, İ, Dikmenli, M., \& Çardak, O. (2008a). Effectiveness of the conceptual change texts accompanied by concept maps about students' understanding of the molecules carrying genetical information. Asia- Pacific Forum on Science Learning and Teaching, 9(1), 1-13.

Taştan ,Ö., Yalçınkaya, E., \& Boz, Y. (2008b).Effectiveness of conceptual change text-oriented instruction on students' understanding of energy in chemical reactions. Journal of Science and Educational Technology. 17, 444-453.

Tekkaya, C. (2003). Remediating high school students' misconceptions concerning diffusion and osmosis through mapping and conceptual change text, Research in Science and Technological Education, 21, 5-16.

Ural Keleş, P. (2009). Kavramsal Değı̧ş̧im Metinleri, Oyun ve Drama ile Zenginleştirilmiş 5e Modelinin Etkililiğinin Belirlenmesi: Canlıları Sinıflandıralım Örneği [Conceptual Change Texts, Determination of Effectiveness of Game and Drama Enriched $5 e$ Model: An Example of Classification of Creatures].Yayınlanmamış Doktora Tezi, KTÜ, Fen Bilimleri Enstitüsü, Trabzon.

Uzuntiryaki E., \& Geban O. (2005). Effect of conceptual change approach accompanied with concept mapping on understanding of solution concepts. Insructional Science, 33, 311-339.

Üce, M., \& Sarıçayır, H. (2002). Üniversite 1. Sınıf Genel Kimya Dersinde Asit- Baz Konusunun Öğretiminde Kavramsal Değişim Metinleri ve Kavram Haritalarının Kullanılması [Usıng Conceptual Changıng Test And Concept Maps To Teach The Subject Of Acıd Bases İn General Chemıstry Course For Preshmen Clases]. M. Ü. Atatürk Eğitim Fakültesi Ĕ̆itim Bilimleri Dergisi, 16, 163-170.

Üce, M. (2009). Teaching the mole concept using a conceptual change method at college level. Education, 129(4), 683-691.

Yalvac, B. (1998). Effect of instruction on students' understanding of electric current concept using conceptual change text at 6th grade. Unpublished Master's Thesis, Middle East Technical University, Ankara.

Yilmaz, O. (1998). The effect of conceptual change texts accompanied with concept mapping on understanding of cell division unit. Unpublished Master Thesis, Middle East Technical University, Ankara.

Yılmaz, D., Tekkaya, C., \& Sungur, S. (2010). The comparative effects of prediction/discussion-based learning cycle, conceptual change text, and traditional instructions on student understanding of genetics. International Journal of Science Education. $1-22$.

Yürük, N. (2007) The effect of supplementing instruction with conceptual change texts on students' conceptions of electrochemical cells. Journal of Science and Educational Technology, 16,515-523. 